\title{
Dynamics of the rangpur lime seed germination test conducted under different temperatures ${ }^{1}$
}

\author{
Marizangela Rizzatti Ávila ${ }^{2}$, Juliana Barbosa ${ }^{3}$, Nelson da Silva Fonseca Júnior ${ }^{2}$, \\ Getúlio Takashi Nagashima², Carolina Maria Gaspar de Oliveira ${ }^{2 *}$ (D), \\ Emanueli Bastos Garcia ${ }^{3}$
}

\begin{abstract}
Adoption of a standard procedure to perform the germination test allows comparison of results between laboratories. Thus, the aim of this study was to evaluate the germination process of rangpur lime (Citrus limonia Osbeck) seeds conducted under different temperatures. The germination test was carried out in five seed lots under three temperatures $\left(25,30\right.$ and $\left.35^{\circ} \mathrm{C}\right)$. The dynamics of the germination process was studied through the following variables: germination (\%), time to first germination (days), time to last germination (days), time interval between first and last germination (days), time required to reach $50 \%$ of germination (days), mean speed of germination $\left(\right.$ day $\left.^{-1}\right)$, synchrony of the germination process (dimensionless), and uncertainty of the germination process (bits). The experimental design was completely randomized, and analysis of variance was performed in a 5 (lots) x 3 (temperatures) factorial arrangement, with four replicates of each treatment. Means were compared using Tukey's test $(\mathrm{p}<0.05)$. The germination process in rangpur lime seeds is slow, homogenous, and asynchronous; and the temperature of $30{ }^{\circ} \mathrm{C}$ is the most favorable for conducting the germination test, with the first count at 21 days and the last at 30 days.
\end{abstract}

Index terms: Citrus limonia Osbeck, rootstock, viability.

\section{Dinâmica do teste de germinação em sementes de limão-cravo conduzido sob diferentes temperaturas}

\begin{abstract}
RESUMO - A adoção de um procedimento padrão na execução do teste de germinação permite a obtenção de resultados comparáveis entre laboratórios. Assim este trabalho objetivou avaliar o processo germinativo em sementes de limão-cravo (Citrus limonia Osbeck) sob diferentes temperaturas. Portanto, realizou-se o teste de germinação utilizando cinco lotes de sementes e três temperaturas $\left(25,30\right.$ e $\left.35^{\circ} \mathrm{C}\right)$. A dinâmica da germinação foi estudada pelas seguintes variáveis: germinação (\%), tempo para a primeira germinação (dias), tempo para a última germinação (dias), intervalo de tempo entre a primeira e a última germinação (dias), tempo médio de germinação (dias), velocidade média de germinação (dia-1), e também pela sincronia do processo de germinação (adimensional) e incerteza do processo de germinação (bits). O delineamento foi inteiramente casualizado, e os dados foram submetidos à análise de variância, com esquema fatorial: 5 (lotes) x 3 (temperaturas), com 4 repetições para cada tratamento. A comparação das médias foi realizada pelo teste de Tukey $(\mathrm{p} \leq 0,05)$. Concluiu-se que o processo germinativo em sementes de limão-cravo é lento, homogêneo e assíncrono, sendo a temperatura de $30{ }^{\circ} \mathrm{C}$ a mais favorável para conduzir o teste de germinação com a primeira contagem aos 21 dias e a última aos 30 dias.
\end{abstract}

Termos para indexação: Citrus limonia Osbeck, porta-enxerto, viabilidade.

\section{Introduction}

Seed commercialization is directly governed by seed lot viability data, which is obtained by germination and/or tetrazolium tests (Brasil, 2013). From these results, the seed producer can compare the physiological quality of seed lots as a parameter for seed commercialization. For seedling producers, the indicators obtained in this test are indispensable
${ }^{1}$ Submitted on 01/24/2019. Accepted for publication on 07/15/2019. ${ }^{2}$ Instituto Agronômico do Paraná (IAPAR). Rodovia Celso Garcia Cid, km 375, 86047-902 - Londrina, PR, Brazil.
${ }^{3}$ Instituto Agronômico do Paraná (IAPAR) - Londrina, PR, Brazil.

*Corresponding author < carolina@iapar.br> 
for planning production.

The germination test is performed under controlled conditions of moisture, temperature, and lighting, and other necessary conditions. These requirements allow germination to occur in a regular, fast, and complete manner, ensuring that the test can be reproduced and that its results can be used for comparison (Brasil, 2009). In Brazil, the methods described in the Rules for Seed Testing (Brasil, 2009) have been adopted for carrying out this test. However, for rangpur lime (Citrus limonia Osbeck), no method has yet been described.

Thus, due to the lack of standardization of the germination test for rangpur lime seeds, studies using different methods appear in the literature. For example, Carvalho et al. (2002) performed the test between paper layers, moistened to 2.5 times the weight of the dry paper, at a temperature of $25^{\circ} \mathrm{C}$, and germinated seeds were counted at 16 and 30 days after setting up the test, using seeds with a seed coat. Dantas et al. (2010) used the same method; however, they counted germinated seeds only on the thirtieth day. Both obtained satisfactory results for seed germination, and they were able to differentiate the treatments used in each study. However, it could not be affirmed that all the seeds were under ideal conditions for germination, since other temperatures were not tested.

There are studies for other species of the Citrus genus, such as tangerine (Citrus reticulata Blanco var. Cleópatra), for which Martins and Silva (2006) performed the germination test at $30^{\circ} \mathrm{C}$ and made evaluations at 21,28 and 35 days after setting up the test. Oliveira et al. (2014) evaluated osmotic conditioning in Citrus volkameriana and conducted the germination test in a roll of paper at $25^{\circ} \mathrm{C}$, with a final count at 45 days. This lack of uniformity of seed testing methods has led to discrepancy among results (Milivojević et al., 2018).

In the case of citrus fruits, it is also necessary to consider that they have recalcitrant seeds, i.e., they have high moisture content, and that they remain metabolically active during storage (Martins and Silva, 2006; Marcos-Filho, 2015). This results in seeds sensitive to desiccation, and they are thus very difficult to store - the seeds lose viability in a short time. Therefore, the germination test must be performed in the shortest time possible, with maximum efficiency and uniformity so that seeds can be quickly sold, avoiding storage (Rodrigues et al., 2010).

Researchers have proposed mathematical expressions to quantify synchronicity, uniformity, and speed of germination (Ranal and Santana, 2006; McNair et al., 2012). Ribeiro-Oliveira and Ranal (2015) affirm that some of these measures have been used over the last two centuries, but intensely discussed and applied in germination studies only in the past decade.
Seed response during the germination process has various quantitative aspects that should be considered, such as time, rate, homogeneity, and synchrony. These are important aspects that can be measured, characterizing the dynamics of this process (Ranal and Santana, 2006).

Thus, the aim of this study was to evaluate the dynamics of the germination test in rangpur lime seeds under different temperatures.

\section{Material and Methods}

The experiment was conducted in the Seed Testing Laboratory of the Instituto Agronômico do Paraná (IAPAR), Londrina, PR, Brazil. Five lots of rangpur lime seeds were used, cultivar IPR 162, genetic category, obtained from fruit gathered from parent plants in 2015 and 2016 at the Luiz Natal Bonin Experimental Station, Cambará, PR (2002'00", $50^{\circ} 06^{\prime} 00^{\prime \prime}$ and altitude of $450 \mathrm{~m}$ AMSL).

The germination test was conducted in a paper roll substrate (PR) with four replications of 50 seeds, arranged on three sheets of paper for germination moistened with distilled water at the proportion of 2.5 times the dry weight of the paper.

The seeds were used with the testa (seed coat), and at sowing, the micropyle was placed in the direction under the fold of the paper, necessary for creating the PR. The rolls were placed in Mangelsdorf germinators, regulated to temperatures of 25,30 and $35^{\circ} \mathrm{C}$, where the seeds remained until termination of the test, with constant lighting with a compact fluorescent bulb (white light) of $220 \mathrm{~V}, 85 \mathrm{~W}$ and $6400 \mathrm{~K}$ (lux).

Evaluations were made daily at the same time, and whenever normal seedlings were found, they were removed from the germination roll and counted. At the end of the test, the ungerminated seeds were separated into the following categories: hard, dormant, and dead. The polyembryonic seeds were also counted.

Normal seedlings were considered to be those that had a root with straight growth, i.e., without twisting or folding and thickening, and that had a length of at least $2 \mathrm{~cm}$, a straight and well-developed hypocotyl, and visible or well-formed leaflets, without damage. The seeds that had germination of more than one seedling (polyembryonic seeds) were likewise considered normal seedlings, and only one seedling was counted, according to Brasil (2009).

Abnormal seedlings were classified as those that do not fit within the description of the seedlings considered normal, but from which a root emerged. Dead seeds were those without a sign of the beginning of germination, as well as seeds that were soft and/or attacked by microorganisms.

With the aim of evaluating the dynamics of the 
germination process by different criteria, after counting was finished, measurements for analysis of germination were determined according to Ranal et al. (2009) for each treatment and replication, which is described below.

\section{Germination ( $G, \%)$}

The percentage of seeds that formed seedlings considered normal was calculated by the following equation:

$$
G=\left(\sum_{i=1}^{k} n_{i} / n\right) 100
$$

where $G$ is germination (\%); $i=1$, the first day of evaluation of the germination test after it was set up; $k$ is the last day of evaluation of the germination test; $n_{i}$ is the number of normal seedlings on day $i$; and $n$ is the total number of seeds placed to germinate ( 50 seeds per roll).

\section{Measurements of germination time}

Time to first germination ( $t_{0}$, days): days necessary to occur the first germination. This time began to be counted when the first normal seedling was observed, according to the germination criterion.

Time to last germination ( $t_{\rho}$ days): days necessary to occur the last germination, i.e., when it was found there would be no more formation of normal seedlings. This was considered the time necessary for conducting the germination test, the end of the test.

Time interval between the first and last germination $\left(t_{0-p}\right.$ days $):$ days necessary between the first and the last germination. This was calculated by counting the days from the occurrence of the first up to the last germination.

Mean germination time $(\bar{t}$, days): average number of days necessary for the formation of normal seedlings through weighting of each day. This was calculated by the following equation:

$$
\bar{t}=\sum_{i=1}^{k} n_{i} t_{i} / \sum_{i=1}^{k} n_{i}
$$

where (days) is mean germination time; $i=1$, the first day of evaluation of the germination test from the day it was set up; $k$ is the last day of evaluation of the germination test; $n_{i}$ is the number of normal seedlings obtained in time $t_{i}$; and $t_{i}$ is the day on which evaluation of the germination test was carried out, which can range from 1 (first day) to $k$ (last day), i.e., not the accumulated days, but rather each day of evaluation.

\section{Measurements of speed of germination}

Mean speed of germination $\left(\bar{v}\right.$, day $\left.{ }^{-1}\right)$ : speed in time (days) in which normal seedlings were obtained. This was calculated by the following equation:

$$
\bar{v}=1 / \bar{t}
$$

where $\bar{t}$ (days) is mean germination time, and it was calculated by previous equation.

Synchrony of the germination process ( $Z$, dimensionless): variation in germination over time, i.e., distribution in time of the fraction of normal seedlings. This was calculated by the following equation:

$$
Z=\sum_{i=1}^{k} C_{n i, 2} / N
$$

where $Z$ is synchrony of the germination process; $i=1$, the first day of evaluation of the germination test from the day it was set up; $k$ : last day of evaluation of the germination test; $C n_{i, 2}$ is combination of normal seedlings in time $i$, two by two; and $N$ is the number of normal seedlings in the entire period of carrying out the germination test.

The term $C n_{i, 2}$ is calculated by the following equation:

$$
C_{n i, 2}=\frac{n_{i}\left(n_{i}-1\right)}{2}
$$

where $C n_{i, 2}$ is the combination of normal seedlings in time $i$, two by two, and $n_{i}$ is the number of normal seedlings on day $i$;

The term $N$ is calculated by the following equation:

$$
N=\sum n_{i}\left(\sum n_{i}-1\right) / 2
$$

where $N$ is the number of normal seedlings in the entire period of carrying out the germination test, and $n_{i}$ is the number of normal seedlings on day $i$. When $\mathrm{Z}=1$, germination of all the normal seedlings occurs on the same day, and $\mathrm{Z}=$ 0 indicates that at least two normal seedlings were able to germinate, one on each day.

Uncertainty of the germination process (I, bits): analyzes the uncertainty associated with distribution of the relative frequency of the germination. It is the measurement that indicates if the process occurred or not. It is calculated by the following equation:

$$
I=-\sum_{i=1}^{k} f_{i} \log _{2} f_{i}
$$

where $I$ is the uncertainty of the germination process; $f_{i}$ is the relative frequency of germination on day $i$; and $\log _{2}$ is the logarithm in base 2 . The $f i$ term is calculated by the following equation:

$$
f_{i}=n_{i} / \sum_{i=1}^{k} n_{i}
$$


where $f i$ is the relative frequency of germination on day $i ; n_{i}$ is the number of germinated seeds on day $i ; k$ is the last day of evaluation of the germination test; and $i=1$, the first day of evaluation of the germination test from the time of being set up.

The experimental design was completely randomized. Analysis of variance was performed by the $F$ test, with $\mathrm{p}<$ 0.05 , respecting the factorial arrangement of 5 (seed lots) $\times 3$ (temperatures), with four replications of 50 seeds, composing a population of 200 seeds for each treatment. In the event of significant interaction, the necessary decompositions were made. Means were compared by the Tukey test at $5 \%$ probability.

\section{Results and Discussion}

Analysis of variance showed that there was statistically significant interaction between seed lots and temperatures for all the parameters studied.

\section{Germination}

The percentage of germination of rangpur lime seeds was statistically equal when the test was conducted at 25 and $30^{\circ} \mathrm{C}$, and these values were higher than those obtained at $35^{\circ} \mathrm{C}$, for all the seed lots (Table 1).

The highest values were observed for seed lots 2 , 4 and 5 at the temperatures of 25 and $30^{\circ} \mathrm{C}$, with values ranging from $86 \%$ to $91 \%$ (Table 1 ). At $35^{\circ} \mathrm{C}$, only lots 4 and 5 had values higher than the others, with results above $60 \%$ germination. Lots 1,2 and 3 obtained a germination percentage below $50 \%$, which would limit the sale of these seeds (Brasil, 2013).

These results show that conducting the germination test of rangpur lime seeds is negatively affected at the temperature of $35{ }^{\circ} \mathrm{C}$, since under this temperature condition, seedling abnormalities were identified (thickening and shortening of roots) and the occurrence of dead seeds.

Various factors can explain the deleterious effect of this temperature on germination; one that stands out is denaturation of enzymes, caused by breaking of the hydrogen bridge bonds that occurs under high temperature (Salisbury and Ross, 2012). These bonds affect organization of membranes and hormone biosynthesis (Bewley et al., 2013).

This suggests that, among the hormones, there was an imbalance between the concentrations of auxin and ethylene, since excess ethylene can reduce the rate of seedling lengthening and promote an increase in lateral expansion (Salisbury and Ross, 2012), as was observed in the higher number of abnormal seedlings, with thicker and shorter roots, at $35^{\circ} \mathrm{C}$.

\section{Measurements of germination time}

Time to first germination ( $t_{0}$, days)

In general, as temperatures increased, the time to first germination decreased (Table 1). However, only the temperatures of 25 and $30{ }^{\circ} \mathrm{C}$ were able to differentiate the seed lots for this characteristic; seed lot 2 was prominent as it had a shorter time to germination than the others.

\section{Time to last germination ( $t_{f}$, days)}

There was a significant difference among the temperatures for all the seed lots regarding time to last germination (Table 1).

The seed lots required a longer time for last germination to occur at $25^{\circ} \mathrm{C}$ than at the other temperatures, which did not differ from each other. A longer time to begin germination was also necessary under this temperature than the other temperatures. More days for conducting and concluding the test are necessary at this temperature.

In addition, comparison of the lots at the different temperatures showed that at $25^{\circ} \mathrm{C}$, there was statistical difference among them. This result indicates that this temperature is not favorable for the germination test of rangpur lime because the ideal situation is for all seed lots to end germination at approximately the same time (McNair et al., 2012).

Thus, the uniformity among the seed lots shown at temperatures of 30 and $35^{\circ} \mathrm{C}$ for the time to last germination characteristic is important for standardization of the germination test because it allows the test to be concluded after a sufficient period so that all the seeds can germinate, regardless of the seed lot.

Nevertheless, although a difference between the temperatures of 30 and $35^{\circ} \mathrm{C}$ was not observed for this characteristic, it should be noted that, as seen above in the results of germination percentage, only the temperature of $30^{\circ} \mathrm{C}$ did not have negative effects on seed germination.

Time interval between the first and last germination ( $t_{0-p}$ days)

In relation to the time interval between the first and last germination (Table 1), a single trend was not observed between the lots and the temperatures; varied responses were found. Thus, in general, fewer days were required between the first and last germination of plants at the temperature of $30{ }^{\circ} \mathrm{C}$ than at the other temperatures. This is an advantage because, according to Bewley et al. (2013), lower values indicate greater uniformity of germination.

\section{Mean germination time ( $\bar{t}$, days)}

A statistical difference was found between mean germination time for each lot in relation to the three temperatures of conducting the germination test (Table 1). The mean germination time $(\bar{t})$ ranged from approximately 20 to 
Table 1. Germination, time to the first and last germination, time interval between the first and last germination, and mean germination time for five seed lots of rangpur lime (Citrus limonia Osbeck), obtained in the germination test conducted under different temperatures.

\begin{tabular}{|c|c|c|c|c|c|c|}
\hline \multicolumn{7}{|c|}{ Germination (\%) } \\
\hline \multirow{2}{*}{$\frac{\text { Temperature }}{\left({ }^{\circ} \mathrm{C}\right)}$} & \multicolumn{5}{|c|}{ Lots } & \multirow{2}{*}{ Means } \\
\hline & 1 & 2 & 3 & 4 & 5 & \\
\hline 25 & $75 \mathrm{Ab}^{1}$ & $90 \mathrm{Aa}$ & $72 \mathrm{Ab}$ & $86 \mathrm{Aa}$ & $89 \mathrm{Aa}$ & 82 \\
\hline 30 & $74 \mathrm{Ab}$ & $90 \mathrm{Aa}$ & $75 \mathrm{Ab}$ & $89 \mathrm{Aa}$ & $91 \mathrm{Aa}$ & 84 \\
\hline 35 & $34 \mathrm{Bc}$ & $45 \mathrm{Bbc}$ & $46 \mathrm{Bb}$ & $61 \mathrm{Ba}$ & $66 \mathrm{Ba}$ & 50 \\
\hline Means & 61 & 75 & 64 & 79 & 82 & \\
\hline \multicolumn{3}{|c|}{ LSD temperatures: 8.96} & \multicolumn{4}{|c|}{ LSD lots: 10.53} \\
\hline \multicolumn{7}{|c|}{ Coefficient of variation (\%): 7.16} \\
\hline \multicolumn{7}{|c|}{ Time to first germination (days) } \\
\hline & 1 & 2 & 3 & 4 & 5 & Means \\
\hline 25 & $19.25 \mathrm{Aab}$ & $15.00 \mathrm{Ac}$ & $17.50 \mathrm{Ab}$ & $18.50 \mathrm{Aab}$ & $20.25 \mathrm{Aa}$ & 18.10 \\
\hline 30 & $15.25 \mathrm{Ba}$ & $12.25 \mathrm{Bb}$ & $14.75 \mathrm{Ba}$ & $16.00 \mathrm{Ba}$ & $15.25 \mathrm{Ba}$ & 14.70 \\
\hline 35 & $12.50 \mathrm{Ca}$ & $12.00 \mathrm{Ba}$ & $13.50 \mathrm{Ba}$ & $12.75 \mathrm{Ca}$ & $13.25 \mathrm{Ca}$ & 12.80 \\
\hline Means & 15.67 & 13.08 & 15.25 & 15.75 & 16.25 & \\
\hline \multicolumn{3}{|c|}{ LSD temperatures: 1.66} & \multicolumn{4}{|c|}{ LSD lots: 1.96} \\
\hline \multicolumn{7}{|c|}{ Coefficient of variation (\%): 6.36} \\
\hline \multicolumn{7}{|c|}{ Time to last germination (days) } \\
\hline & 1 & 2 & 3 & 4 & 5 & Means \\
\hline 25 & $35.00 \mathrm{Aa}$ & $32.00 \mathrm{Ac}$ & $33.50 \mathrm{Ab}$ & $35.00 \mathrm{Aa}$ & $35.00 \mathrm{Aa}$ & 34.10 \\
\hline 30 & $31.00 \mathrm{Ba}$ & $30.50 \mathrm{Ba}$ & $30.50 \mathrm{Ba}$ & $30.50 \mathrm{Ba}$ & $30.25 \mathrm{Ba}$ & 30.55 \\
\hline 35 & $30.25 \mathrm{Ba}$ & $30.00 \mathrm{Ba}$ & $30.00 \mathrm{Ba}$ & $31.00 \mathrm{Ba}$ & $31.00 \mathrm{Ba}$ & 30.45 \\
\hline Means & 32.08 & 30.83 & 31.33 & 32.17 & 32.08 & \\
\hline \multicolumn{3}{|c|}{ LSD temperatures: 1.13} & \multicolumn{4}{|c|}{ LSD lots: 1.32} \\
\hline \multicolumn{7}{|c|}{ Coefficient of variation (\%): 2.06} \\
\hline \multicolumn{7}{|c|}{ Time interval between the first and last germination (days) } \\
\hline & 1 & 2 & 3 & 4 & 5 & Means \\
\hline 25 & $15.75 \mathrm{Bab}$ & $17.00 \mathrm{Aa}$ & $16.00 \mathrm{Aab}$ & $16.50 \mathrm{Aab}$ & $14.75 \mathrm{Bb}$ & 16.00 \\
\hline 30 & $15.75 \mathrm{Bb}$ & $18.25 \mathrm{Aa}$ & $15.75 \mathrm{Ab}$ & $14.50 \mathrm{Bb}$ & $15.00 \mathrm{Bb}$ & 15.85 \\
\hline 35 & $17.75 \mathrm{Aa}$ & $18.00 \mathrm{Aa}$ & $16.50 \mathrm{Aa}$ & $18.25 \mathrm{Aa}$ & $17.75 \mathrm{Aa}$ & 17.65 \\
\hline Means & 16.42 & 17.75 & 16.08 & 16.42 & 15.83 & \\
\hline \multicolumn{3}{|c|}{ LSD temperatures: 1.88} & \multicolumn{4}{|c|}{ LSD lots: 2.21} \\
\hline \multicolumn{7}{|c|}{ Coefficient of variation (\%): 6.60} \\
\hline \multicolumn{7}{|c|}{ Mean germination time (days) } \\
\hline & 1 & 2 & 3 & 4 & 5 & Means \\
\hline 25 & $25.58 \mathrm{Aab}$ & $22.06 \mathrm{Ac}$ & $25.13 \mathrm{Ab}$ & $26.32 \mathrm{Aab}$ & $26.64 \mathrm{Aa}$ & 25.15 \\
\hline 30 & $21.99 \mathrm{Ba}$ & $19.34 \mathrm{Bb}$ & $21.68 \mathrm{Ba}$ & $21.72 \mathrm{Ca}$ & $21.92 \mathrm{Ca}$ & 21.33 \\
\hline 35 & $20.59 \mathrm{Cb}$ & $18.00 \mathrm{Cc}$ & $21.11 \mathrm{Bb}$ & $24.04 \mathrm{Ba}$ & $23.54 \mathrm{Ba}$ & 21.46 \\
\hline Means & 22.72 & 19.80 & 22.64 & 24.03 & 24.03 & \\
\hline \multicolumn{3}{|c|}{ LSD temperatures: 1.22} & \multicolumn{4}{|c|}{ LSD lots: 1.43} \\
\hline & & & of variation & & & \\
\hline
\end{tabular}

${ }^{1}$ Mean values followed by the same uppercase letter in the column and lowercase letter in the row do not differ from each other by the Tukey test at $5 \%$ probability. LSD $=$ Least significant difference. 
24 days. In comparison of the lots at the three temperatures tested, lot 2 differed significantly from the others, with the lowest mean germination time.

For all the lots, there was significant difference among the temperatures, and the mean germination time at $25^{\circ} \mathrm{C}$ was greater than the others. However, considering that at $35^{\circ} \mathrm{C}$, lots 1, 2 and 3 exhibited mean germination values lower than $50 \%$, it can be affirmed that the temperature of $30{ }^{\circ} \mathrm{C}$ stood out by providing greater speed in the process and a higher germination percentage.

These results correlate with the theoretical foundation that states that the higher the temperature, the greater the speed of reactions and, thus, the shorter the mean germination time (Bewley et al., 2013). Other authors studying the germination process also observed difference in mean germination time at different temperatures. For example Lopes and Franke (2011), who studied the effect of temperature on germination of bird's- foot trefoil (Lotus corniculatus L.) seeds, and also Pacheco et al. (2008), who worked with the effect of temperature on the germination process of Tabebuia aurea and found that at 30 and $35^{\circ} \mathrm{C}$, imbibition speed is greater, accelerating metabolic reactions and, consequently, speed of germination.

Furthermore, Bello et al. (2008) studied the germination of Amburana acreana seeds and found that at temperatures of 20 and $25^{\circ} \mathrm{C}$, germination was slower, achieving lower potential, and when conducted at $40{ }^{\circ} \mathrm{C}$, normal seedlings were not formed, due to disorder occurring in the plasmatic membrane.

\section{Measurements of speed of germination}

Mean speed of germination ( $\bar{v}$, day $\left.^{-1}\right)$

The results of mean speed of germination indicated that there was statistically significant interaction in relation to the three temperatures analyzed for all the lots (Table 2). Thus, a pattern of response could not be observed among

Table 2. Mean speed of germination, synchrony of the germination process, and uncertainty of the germination process for five seed lots of rangpur lime (Citrus limonia Osbeck), obtained in the germination test conducted under different temperatures.

\begin{tabular}{|c|c|c|c|c|c|c|}
\hline \multicolumn{7}{|c|}{ Mean speed of germination $\left(\bar{v}\right.$, day $\left.^{-1}\right)$} \\
\hline \multicolumn{3}{|l|}{ Temperature } & \multicolumn{3}{|l|}{ Lots } & \multirow{2}{*}{ Means } \\
\hline$\left({ }^{\circ} \mathrm{C}\right)$ & 1 & 2 & 3 & 4 & 5 & \\
\hline 25 & $0.039 \mathrm{Cb}^{1}$ & $0.045 \mathrm{Ca}$ & $0.039 \mathrm{Bb}$ & $0.038 \mathrm{Cb}$ & $0.037 \mathrm{Cb}$ & 0.040 \\
\hline 30 & $0.045 \mathrm{Bb}$ & $0.051 \mathrm{Ba}$ & $0.046 \mathrm{Ab}$ & $0.046 \mathrm{Ab}$ & $0.045 \mathrm{Ab}$ & 0.047 \\
\hline 35 & $0.048 \mathrm{Ab}$ & $0.055 \mathrm{Aa}$ & $0.047 \mathrm{Ab}$ & $0.041 \mathrm{Bc}$ & $0.042 \mathrm{Bc}$ & 0.047 \\
\hline Means & 0.044 & 0.050 & 0.044 & 0.042 & 0.041 & \\
\hline \multicolumn{3}{|c|}{ LSD temperatures: 0.0026} & \multicolumn{4}{|c|}{ LSD lots: 0.0029} \\
\hline \multicolumn{7}{|c|}{ Coefficient of variation (\%): 2.97} \\
\hline \multicolumn{7}{|c|}{ Synchrony of the germination process $(Z$, dimensionless $)$} \\
\hline & 1 & 2 & 3 & 4 & 5 & Means \\
\hline 25 & $0.08 \mathrm{Aa}$ & $0.08 \mathrm{Ba}$ & $0.07 \mathrm{Aa}$ & $0.07 \mathrm{ABa}$ & $0.07 \mathrm{ABa}$ & 0.07 \\
\hline 30 & $0.07 \mathrm{ABa}$ & $0.08 \mathrm{Ba}$ & $0.08 \mathrm{Aa}$ & $0.08 \mathrm{Aa}$ & $0.08 \mathrm{Aa}$ & 0.08 \\
\hline 35 & $0.06 \mathrm{Bb}$ & $0.12 \mathrm{Aa}$ & $0.07 \mathrm{Ab}$ & $0.06 \mathrm{Bb}$ & $0.06 \mathrm{Bb}$ & 0.08 \\
\hline Means & 0.07 & 0.09 & 0.08 & 0.07 & 0.07 & \\
\hline \multicolumn{3}{|c|}{ LSD temperatures: 0.013} & \multicolumn{4}{|c|}{ LSD lots: 0.015} \\
\hline \multicolumn{7}{|c|}{ Coefficient of variation (\%): 10.19} \\
\hline \multicolumn{7}{|c|}{ Uncertainty of the germination process $(I$, bits $)$} \\
\hline & 1 & 2 & 3 & 4 & 5 & Means \\
\hline 25 & $3.62 \mathrm{Aa}$ & $3.69 \mathrm{Aa}$ & $3.69 \mathrm{Aa}$ & $3.73 \mathrm{ABa}$ & $3.78 \mathrm{Aa}$ & 3.70 \\
\hline 30 & $3.78 \mathrm{Aa}$ & $3.78 \mathrm{Aa}$ & $3.70 \mathrm{Aa}$ & $3.66 \mathrm{Ba}$ & $3.71 \mathrm{Aa}$ & 3.73 \\
\hline 35 & $3.60 \mathrm{Ab}$ & $3.06 \mathrm{Bc}$ & $3.57 \mathrm{Ab}$ & $3.86 \mathrm{Aa}$ & $3.87 \mathrm{Aa}$ & 3.59 \\
\hline Means & 3.67 & 3.51 & 3.65 & 3.75 & 3.79 & \\
\hline \multicolumn{3}{|c|}{ LSD temperatures: 0.18} & \multicolumn{4}{|c|}{ LSD lots: 0.22} \\
\hline \multicolumn{7}{|c|}{ Coefficient of variation (\%): 2.97} \\
\hline
\end{tabular}

${ }^{1}$ Mean values followed by the same uppercase letter in the column and lowercase letter in the row do not differ from each other by the Tukey test at $5 \%$ probability. LSD $=$ Least significant difference. 
the parameters studied. Greater speed of germination was observed at the temperature of $35^{\circ} \mathrm{C}$ for lots 1 and 2, and at the temperature of $30{ }^{\circ} \mathrm{C}$ for lots 4 and 5 . In general, mean speed of germination was lower for all the lots when the test was conducted at $25^{\circ} \mathrm{C}$.

A significant difference was found among the lots, especially lot 2, which had a higher mean speed of germination at all the temperatures. These results are similar to those found for mean germination time (Table 1). Thus, they are in agreement with the premise that when the mean speed of germination is near zero, it indicates that the germination process is slow, thus exhibiting a longer mean germination time (Ranal et al., 2009).

\section{Synchrony of the germination process ( $Z$, dimensionless)}

In synchrony of the germination process, there was significant statistical interaction among the factors. Only lot 3 did not differ significantly in relation to the temperatures. Lots 4 and 5 exhibited greater synchrony at $30^{\circ} \mathrm{C}$, lot 1 at $25^{\circ} \mathrm{C}$ and lot 2 at $35^{\circ} \mathrm{C}$ (Table 2).

When all the lots were compared within each temperature, they did not show significant difference for synchrony of the germination process at $25^{\circ} \mathrm{C}$ and at $30^{\circ} \mathrm{C}$. However, at $35^{\circ} \mathrm{C}$, lot 2 was statistically different in relation to the others, showing a higher result.

This difference in synchrony among the lots at $35{ }^{\circ} \mathrm{C}$ has negative consequences for the germination test, because irregularity in germination over time makes it impossible to determine dates of the first and last count for the test (Milivojević et al., 2018).

In nurseries, low synchrony of seed germination hurts uniformity and formation of stand, and this increases the risk of deterioration of the seeds that remain longer in the soil or in another substrate necessary for germination (Rodrigues et al., 2010). Knowledge of the optimal temperature that may favor synchronization of the process for germination of rangpur lime seeds is fundamental for the seedling producer to have uniform plants.

\section{Uncertainty of the germination process (I, bits)}

In the results of uncertainty of germination in comparison of the temperatures for each lot tested, lots 1,3 and 5 did not show significant difference at any of the temperatures tested, i.e., the uncertainty of the germination process was the same, regardless of the temperature used for conducting the germination test.

In lots 2 and 4 , there was statistical difference. For lot 2 at the temperature of $35^{\circ} \mathrm{C}$, there was lower uncertainty of the germination process than at $25{ }^{\circ} \mathrm{C}$ and $30^{\circ} \mathrm{C}$, which did not differ from each other. In lot 4 , lower values were observed at
$30{ }^{\circ} \mathrm{C}$ than at $35^{\circ} \mathrm{C}$, but these values did not differ from $25^{\circ} \mathrm{C}$.

Comparison of all the lots within each temperature showed that the germination conducted at the temperatures of $25{ }^{\circ} \mathrm{C}$ and $30{ }^{\circ} \mathrm{C}$ did not differ for uncertainty of the germination process. In regard to the temperature of $35^{\circ} \mathrm{C}$, lot 2 showed the lowest value, followed by lots 4 and 5 , which did not differ statistically from each other but stood out with higher values, i.e., greater uncertainty of the germination process.

All the results of uncertainty of the germination process indicate that this is a variable process, i.e., inconstant process.

Thus, for rangpur lime seeds, the germination process is distributed over time, and considered asynchronous and variable, i.e., when at least two seeds germinate at different times, indicating that germination did not overlap. This can be observed by the amplitude in the germination process (Table 1) (long period between the first and last germination), high uncertainty values (far from zero) (Table 2), and low synchrony value (near zero) (Ranal et al., 2009).

The results of this study corroborate the literature, because it was observed that in the absence of other limiting factors, seed germination occurs under wide temperature limits, whose extremes depend on diverse factors. In addition, temperature variation affects the speed, time, percentage, and uniformity of the germination process, and these factors need to be determined for efficiency of the germination process (Bewley et al., 2013; Marcos-Filho, 2015).

\section{Conclusions}

The germination test of rangpur lime seeds should be conducted under the temperature of $30{ }^{\circ} \mathrm{C}$, performing first count at 21 days and final count at 30 days.

The temperature of $25^{\circ} \mathrm{C}$ is favorable for germination of rangpur lime seeds; however, 35 days are needed to conclude the test.

The temperature of $35{ }^{\circ} \mathrm{C}$ hurts the germination performance of rangpur lime seeds, and it is not recommended for conducting the germination test.

\section{References}

BELLO, E.P.B.C.S.; ALBUQUERQUE, M.C.F.; GUIMARÃES, S.C.; MENDONÇA, E.A.F. Germinação de sementes de Amburana acreana (Ducke) A. C. Sm. submetidas a diferentes condições de temperatura e de estresse hídrico. Revista Brasileira de Sementes, v.30, n.3, p.16-24, 2008. http://www.scielo.br/pdf/rbs/v30n3/03.pdf

BEWLEY, J.D.; BRADFORD, K.; HILHORST, H.; NONOGAKI, H. Seeds: physiology of development, germination and dormancy. $3^{\mathrm{a}}$ ed. Springer Verlag: New York, 2013. 392p. https://www.springer. com/la/book/9781461446927 
BRASIL. Ministério da Agricultura, Pecuária e Abastecimento. Regras para análise de sementes. Ministério da Agricultura, Pecuária e Abastecimento. Secretaria de Defesa Agropecuária. Brasília, DF: MAPA/ACS, 2009. 395p. http://www.agricultura.gov.br/assuntos/ insumos-agropecuarios/arquivos-publicacoes-insumos/2946 regras_analise_sementes.pdf

BRASIL. Ministério da Agricultura, Pecuária e Abastecimento. Normas para produção, comercialização e utilização de sementes. Padrões para produção e comercialização de sementes de Citrus. Instrução Normativa $n^{\circ} 48$, anexo XV. Diário Oficial da União, Brasil, 25 de setembro de 2013. Seção 1. p.38. https://www.defesa. agricultura.sp.gov.br/legislacoes/instrucao-normativa-n-48-de-24de-setembro-de-2013,1136.html

CARVALHO, J.A.; VON PINHO, E.V.R.; OLIVEIRA, J.A.; GUIMARÃES, R.M.; BONOME, L.T. Qualidade de sementes de limão-cravo (Citrus limonia Osbeck) durante o armazenamento. RevistaBrasileiradeSementes, v.24,n.1,p.286-298,2002.http://www. scielo.br/scielo.php?pid=S0101-31222002000100040\&script $=$ sci abstract\&tlng $=\mathrm{pt}$

DANTAS, I.B.; GUIMARÃES, R.M.; VON PINHO, E.V.R.; CARVALHO, M.L.M. Osmotic priming methodologies in relation to the physiological performance of rangpur lime seeds (Citrus limonia Osbeck). Revista Brasileira de Sementes, v.32, n.3, p.141-151, 2010. http://www.scielo.br-/pdf/rbs/v32n3/v32n3a16.pdf

LOPES, R.R.; FRANKE, L.B. Aspectos térmico-biológicos da germinação de sementes de cornichão anual sob diferentes temperaturas. Revista Brasileira de Zootecnia, v.40, n.10, p.20912096, 2011. http://www.scielo.br/pdf/rbz/v40n10/v40n10a04.pdf

MARCOS-FILHO, J. Fisiologia de sementes de plantas cultivadas. $2^{\mathrm{a}}$ ed. Londrina: ABRATES, 2015. 659p.

MARTINS, L.; SILVA, W.R. Comportamento fisiológico de sementes de tangerina (Citrus reticulata Blanco) submetidas à desidratação. Revista Brasileira de Fruticultura, v.28, n.1, p.8-10, 2006. http://www. scielo.br/scielo.php?pid=S0100-9452006000100005\&script $=$ sci abstract\&tlng $=\mathrm{pt}$

McNAIR, J.N.; SUNKARA, A.; FROBISH, D. How to analyse seed germination data using statistical time-to-event analysis: nonparametric and semi-parametric methods. Seed Science Research, v.22, n.2, p.77-95, 2012. https://www.cambridge.org/core/journals/seedscience-research/article/how-to-analyse-seed-germination-data-usingstatistical-timetoevent-analysis-nonparametric-and-semiparametric-met hods/257AFB74E845B5792FD8FEE27ADE03B4
MILIVOJEVIĆ, M.; RIPKA, Z.; PETROVIĆ, T. ISTA rules changes in seed germination testing at the beginning of the $21^{\text {st }}$ century. Journal on Processing and Energy in Agriculture, v.22, n.1, p.40-45, 2018. http://scindeks.ceon.rs/article.aspx?artid=1821$44871801040 \mathrm{M}$

OLIVEIRA, A.S.; SANTOS, M.F.; FERREIRA, R.A.; BLANK, A.F.; SILVA-MANN, R. Condicionamento osmótico em sementes de limão 'Volkameriano' (Citrus volkameriana Tan. and Pasq.). Scientia Plena, v.10, n.9, p.1-9, 2014. https://scientiaplena.org.br-/ $\mathrm{sp} /$ article/view/1777

PACHECO, M.V.; MATOS, V.P.; FELICIANO, A.L.P; FERREIRA, R.L.C. Germinação de sementes e crescimento inicial de plântulas de Tabebuia aurea (Silva Manso) Benth. and Hook f. ex S. Moore. Ciência Florestal, v.18, n.2, p.143-150, 2008. http://www.scielo.br/ pdf/cflo/v18n2/1980-5098-cflo-18-02-00143.pdf

RANAL, M.A.; SANTANA, D.G. How and why to measure the germination process? Brazilian Journal of Botany, v.29, n.1, p.1-11, 2006. http://www.scielo.br/scielo.php?pid=S0100$84042006000100002 \&$ script $=$ sci_arttext\&tlng=pt

RANAL, M.A.; SANTANA, D.G.; FERREIRA, W.R.; MENDESRODRIGUES, C. Calculating germination measurements and organizing spreadsheets. Revista Brasileira de Botânica, v.32, n.4, p.849-855, 2009. http://www.scielo.br/pdf/rbb/v32n4/a22v32n4.pdf

RIBEIRO-OLIVEIRA, J.P.; RANAL, M.A. Sample size in studies on the germination process. Botany, v.94, n.2, p.103-115, 2015. http:// www.nrcresearchpress.com/doi/abs/10.1139/cjb-2015-0161\#.W$\mathrm{HKa} 5 \mathrm{NKjIU}$

RODRIGUES, F.A.; FREITAS, G.F.; MOREIRA, R.A.; PASQUAL, M. Caracterização dos frutos e germinação de sementes dos portaenxertos trifoliata Flying Dragon e Citrumelo Swingle. Revista Brasileira de Fruticultura, v.32, n.4, p.1180-1188, 2010. http:// www.scielo.br/pdf/rbf/v32n4/-AOP12610.pdf

SALISBURY, F.B.; ROSS, C.W. Fisiologia das plantas. Cengage Learning. Wadsworth: Belmont, 2012. 774p. 